\title{
GOVERNMENT OFFICERS AS DEFENDANTS: TWO TROUBLESOME PROBLEMS
}

\section{Kenneth Culp Davis $\dagger$}

A plaintiff who wants to compel or to enjoin governmental action usually escapes the doctrine of sovereign immunity by suing an officer. The courts are accustomed to indulging in the fiction that such a suit is not against the government, even though all concerned are fully aware that it is. The question whether or when sovereign immunity is a defense in such a suit against an officer has been treated elsewhere. ${ }^{1}$ This paper is concerned with the two incidental but troublesome problems of superior officers as indispensable parties in suits against subordinate officers, and the substitution of successors of officers who are named as defendants.

On the first of these two problems, only slight exaggeration is involved in the statement that eight Supreme Court decisions provide eight solutions. On the second problem, the Advisory Committee on Rules for Civil Procedure has asserted that "the substitution of one nominal party for another nominal party is a time-consuming formality," but proposes to continue the requirement of the formality. ${ }^{2}$ Both problems happily seem to be susceptible to satisfactory solution.

\section{Supertor Officers as Indispensable Parties}

The law that superior officers are sometimes indispensable parties in suits to enjoin or to compel action by subordinate officers is not only wholly judge-made, but it has been remade frequently by the Supreme Court. Despite the obvious need for clarity and simplicity on this subordinate but often decisive question of procedural law, the result has been over a period of several decades an almost complete unpredictability of decisions either of the Supreme Court or of lower federal courts.

Unless a statute permits a suit against an agency or against the United States, a suit in a federal court challenging administrative

$\dagger$ Professor of Law, University of Minnesota Law School. A.B., 1931, Whitman College; LL.B., 1934, Harvard Law School.

1. Davis, Sovereign Immunity in Suits Against Officers for Relief Other Than Damages, 40 CORNEIL L.Q. 3 (1954).

2. Preliminary Draft of Proposed Amendiments to Rules of Civil Procedure for the United States District Courts 20 (May 1954). 
action must be brought against an officer. A suit against a field officer, who can be locally served, is usually more convenient to a plaintiff than a suit against the agency head, who normally can be served and sued only in the District of Columbia. The question whether an agency head or superior officer is an indispensable party therefore arises frequently. $^{3}$ The one proposition that is clear in the case law is that sometimes a superior is an indispensable party and sometimes not.

Before the 1955 decision in Shaughnessy v. Pedreiro, which takes a wholly new approach, the key case was the 1947 decision in Williams v. Fanning. ${ }^{5}$ The action was brought against the postmaster at Los Angeles to enjoin enforcement of a fraud order. In holding that the Postmaster General, in whose name the fraud order had been issued, was not an indispensable party, the Court laid down what is supposed to be the guiding principle: ". . . [T] he superior officer is an indispensable party if the decree granting the relief sought will require him to take action, either by exercising directly a power lodged in him or by having a subordinate exercise it for him." "

The Court strangely-perhaps facetiously-acknowledged that the principle it enunciated was ". . . not as clear to others as it seems to us." 7 The Court evidently did not see the difficulties that others see in applying the principle. Those difficulties involve the distinction between action and inaction, and the distinction between action of a subordinate and action of a superior through a subordinate. To apply the principle to the Williams case, one has to inquire whether an injunction against enforcement of a fraud order requires the Postmaster General, who issued the fraud order, ". . . to take action, either by exercising directly a power lodged in him or by having a subordinate exercise it for him." The first step is to discover whether the injunction against enforcement of the fraud order requires anyone "to take action." To stop enforcing the fraud order is in one sense wholly negative. But the mechanics, presumably, will involve an act of the Los Angeles postmaster to direct his subordinates to deliver mail to the particular addressee instead of returning it to senders. To say that that is "an act," as distinguished from mere inaction, seems en-

3. The problem of whether a subordinate is an indispensable party in a suit against a superior seldom arises. In Miguel v. McCarl, 291 U.S. 442, 455 (1934), the Court said: "The purpose of the suit was to control the action of the Chief of Finance, that is, to compel him to pay or cause to be paid the voucher in question. The disbursing officer as the mere agent of his superior officer is not an indispensable, although he might have been joined as a proper, party."

4. 349 U.S. 48 (1955).

5. 332 U.S. 490 (1947).

6. Id. at 493.

7. $I d$. at 494 . 
tirely reasonable. If it is an act, whose act is it? Is it the act of the Los Angeles postmaster, or is the Postmaster General taking the action “. . . either by exercising directly a power lodged in him or by having a subordinate exercise it for him"? This question seems. impossible to answer. But the Court answered it: "It is [the local postmaster] who . . . places the stamp 'fraudulent' on the mail, who returns the mail to the senders. If he desists in those acts, the matter is at an end. That is all the relief which petitioners seek. The decree in order to be effective need not require the Postmaster General to do a single thing-either directly as in the Smith and Fall cases or indirectly through his subordinate as in the Rutter case." 8

The Postmaster General, then, is not acting "indirectly through his subordinate as in the Rutter case" when the Los Angeles postmaster lifts the fraud order by directing that the mail be delivered to the addressee. We turn to Gnerich v. Rutter ${ }^{9}$ to find out when a superior does act "indirectly through his subordinate." The suit was to enjoin local prohibition officers from enforcing a restriction on a pharmacist's permit to sell intoxicants. The Supreme Court unequivocally declared that the local officers ". . . are mere agents and subordinates of the Commissioner. . . . What they do is as if done by him. He is the public's real representative in the matter, and, if the injunction were granted, his are the hands which would be tied. All this being so, he should have been made a party defendant. . . ."10

The crucial question the Court did not answer in the Williams opinion is why the Court in the Williams case did not use the reasoning the Court used in the Rutter case. On the authority of Rutter the Court could have reasoned in Williams, as in Rutter, that the local postmaster and his assistants "are mere agents and subordinates" of the Postmaster General. "What they do is as if done by him. He is the public's real representative in the matter, and, if the injunction were granted, his are the hands which would be tied."

What emerges, then, is a principle that the superior officer is an indispensable party if the decree granting the relief sought will require him to take action either personally or through a subordinate. When local officers put a restriction on a license, an injunction against enforcement of the restriction ties the hands of the superior officer, who

8. Ibid. The Court assumes that the fraud order issued by the Postmaster General remains outstanding after the court enjoins its enforcement. Of course, some one on behalf of the Postmaster General is likely to take action to withdraw it.

The Court is speaking quite unrealistically when it says that the local postmaster ". . . places the stamp 'fraudulent' on the mail. ..." Like the Postmaster General, the Los Angeles postmaster necessarily acts principally through assistants.

9. 265 U.S. 388 (1924).

10. Id. at 391 . 
is therefore an indispensable party. When the Postmaster General issues a fraud order, an injunction against enforcement of the order does not tie the hands of the Postmaster General, who is therefore not an indispensable party. And the Court went out of its way to pretend that the Williams result was consistent with the Rutter result.

This is the principal fountainhead from which the confusion has flowed on the question whether a superior officer is an indispensable party in an action to challenge action of a local officer.

Additional confusion has been caused by the Court's pretense in the Williams opinion that three other prior decisions, as well as the Rutter case, were reconcilable with each other and with "the principle" laid down in the Williams opinion. In Warner Valley Stock Co. v. $S m i t h{ }^{11}$ the plaintiff sought not only an injunction against both the Commissioner of the General Land Office and the Secretary of the Interior but also an order directing the Secretary to issue land patents. After the Secretary resigned, the Court held that the Secretary was indispensable because "the purpose of the bill was to control the action of the Secretary. . . ." ${ }_{12}$ But since the purpose of the suit in the Williams case was to challenge a fraud order issued by the Postmaster General, was not the purpose of the bill to control the action of the Postmaster General?

Webster $v$. Fall ${ }^{13}$ was a suit to require local disbursing officers to make a payment of money. The Court held the Secretary of the Interior indispensable because "the statutory direction to cause quarterly payments to be made . . . is addressed to the Secretary. The power and responsibility are his." 14 Of course, the statutory direction to issue fraud orders is addressed to the Postmaster General. The power and responsibility are his. But the Court purports to extract "the principle" of the Williams case from the four cases of which the Webster case is one.

In Colorado v. Toll, ${ }^{15}$ a superior officer who issued a regulation forbidding operation of automobiles for hire in a national park was not an indispensable party in a suit to enjoin enforcement of the regulation; the only reason given was that the suit was ". . . to restrain an individual from doing acts that it is alleged that he has no authority to do. . . ."16 The Court apparently had forgotten the idea of the Rutter case that the injunction would tie the hands of the superior,
11. 165 U.S. 28 (1897).
12. Id. at 34 .
13. 266 U.S. 507 (1925).
14. Id. at 510 .
15. 268 U.S. 228 (1925).
16. Id. at 230 . 
and it had apparently forgotten the idea of the Webster case that "the 'power and responsibility". are the superior's. .The Toll case supports the Williams holding, but it does not support the pretense of the Williams opinion that the line of decisions was straight.

In the first two decisions since the Williams case, the Supreme Court has done nothing to dispel the confusion, and the second of them is difficult to reconcile with Williams. The first of the two, Hynes $v$. Grimes Packing $\mathrm{Co}_{0 .}{ }^{17}$ applies the Williams principle without difficulty. The suit was to enjoin a regional director in Alaska from enforcing regulations issued by the Secretary of the Interior prohibiting certain fishing in Alaskan waters. Applying the Williams test, the Court held that the Secretary was not an indispensable party: "Nothing is required of the Secretary; he does not have to perform any act, either - directly or indirectly. Respondents merely seek an injunction restraining petitioner from interfering with their fishing. No affirmative action is required of petitioner, and if he and his subordinates cease their interference, respondents have been accorded all the relief. which they seek." 18

The Grimes case seems quite satisfactory in its emphasis upon the idea that the Court may order the subordinate to ignore both the superior's instructions and the formal regulations issued by the superior. Judge Learned Hand once indulged in the plausible reasoning that a superior officer must be made a party to avoid leaving the subordinate under a command of his superior to do what the court forbids. ${ }^{19}$ This reasoning is authoritatively rejected by the Grimes case; it had already been discredited by the remark in the Willians opinion that the superior's command to do what the court forbids is ". . . immaterial if the decree which is entered will effectively grant the relief desired by expending itself on the subordinate. . .."20

The 1952 decision in Blackmar $v$. Guerre ${ }^{21}$ may be inconsistent with both Williams and Grimes. A federal employee sought a declaratory judgment that he had been illegally discharged. A regional office of the Civil Service Commission had held in his favor but had been reversed by the Commission in Washington. Since service had been made upon the discharging officer, Guerre, the Court could have held, in accordance with "the principle" enunciated in the Williams opinion and followed in the Grimes opinion, that a declaratory judgment that

I7. 337 U.S. 86 (1949).

18. Id. at 97.

19. National Conference v. Goldman, 85 F.2d 66 (2d Cir. 1936).

20. 332 U.S. at 494.

21. 342 U.S. 512 (1952). 
Guerre was legally obligated to reinstate the plaintiff did not require affirmative action either by the Civil Service Commission or by its members. Instead, the Supreme Court disposed of the whole issue of indispensable parties by saying of Guerre, without amplification, that ". . . it is obvious that no relief can be granted against him." 22

But why is it obvious that the man who discharged the plaintiff may not be the defendant in a suit for a declaration that the discharge was illegal? Why is it not obvious, instead, that the man who commits the challenged act is the proper party defendant, especially since the Williams and Grimes cases establish the proposition that a court may order a subordinate to violate the orders of his superior?

Perhaps the Court assumed in the Blackmar opinion that review of the Civil Service Commission's decision is improper unless either the Commission or the commissioners are parties. But this assumption is contrary to a good deal of tradition. After the Postmaster General (or some other high official acting for him) makes a decision to issue a fraud order, a court may enjoin enforcement of the order in a suit against a local postmaster. ${ }^{23}$ The familiar practice of more than half a century in alien cases allows a writ of habeas corpus against the local officer to challenge a decision which has been made by the immigration inspector, affirmed by the board of appeals, and again affirmed by the Attorney General. ${ }^{24}$

Before the Supreme Court's 1955 decision in the Pedreiro case, the lower courts had as guides the unintelligible "principle" of the Williams case and seven conflicting Supreme Court decisions. Almost any routine case can be used to illustrate the confusion and unpredictability. For instance, a landlord sued a local officer for a declaratory-judgment that an increase in rent was less than the statute required. Was the Housing Expediter an indispensable party? Could the court grant the relief sought without requiring the Expediter to take action either personally or through a subordinate? Under the Williams "principle," if the subordinate should grant the further increase sought, would his act be that of the Expediter. acting through him? Under the Williams case, could a decree granting relief expend itself on the subordinate? Under the Webster case, is the Expediter

22. Id. at 515 .

23. This is not only the holding in Williams v. Fanning, 332 U.S. 490 (1947), but the Court there said: "Beginning at least with American School of Magnetic Healing v. McAnnulty, 187 U.S. 94, decided in 1902, the maintenance of the suit against the local postmaster alone was not challenged." Id. at 492 . (Footnote omitted).

24. The practice rests upon a habeas corpus statute, which is now 62 Star. 965 (1948), 28 U.S.C. $\$ 2243$ (1952): "The writ, or order to show cause shall be directed to the person having custody of the person detained." 
indispensable because "the power and responsibility are his"? Under Gnerich v. Rutter, must the Expediter be joined because "his are the hands which would be tied"? Or does a declaratory judgment tie anybody's hands? Should the Grimes case be invoked for the proposition that "nothing is required of the Secretary [the Expediter]; he does not have to perform any act, either directly or indirectly"?

Which of the various guides should the lower court follow? The court of appeals, citing five unreported decisions to the same effect, held that the Expediter was an indispensable party. ${ }^{25}$

Trying to predict holdings of lower courts has been an intriguing but unprofitable pastime. An informed lawyer might have guessed that in a suit for an injunction and a declaratory judgment against local Army and Coast Guard officers, the court would hold that national officers were not indispensable because the relief sought was entirely negative in the sense that no act was required. ${ }^{26}$ But the informed lawyer's predicting average would be reduced to thirty-three per cent if he applied the same approach to a pair of rent cases. A plaintiff who sought a declaratory judgment that his housing was not subject to regulation lost his case in the court of appeals for failure to join the Expediter, because "this is not the type of case where "the decree, if granted, would expend itself on the subordinate." 27 The court did not explain this remark; the informed lawyer might think it would be easier to explain an opposite statement. A plaintiff who sued the area director to enjoin regulation of rents and for a declaratory judgment that his apartment house was not subject to rent control was denied relief partly for failure to join the Expediter. Surprisingly, the court reasoned that under the Williams case the Expediter was not indispensable for an injunction but.went on to hold that the injunction “. . . was only incidental to the main relief sought, which was a decree adjudicating that the leased premises were not subject to rent control. . . . A decree could not effectively grant such principal relief unless it bound the Housing Expediter, and such a decree, if binding on the Housing Expediter, would interfere with the public administration of rent control. An action for such principal relief could not be maintained without joining the Housing Expediter as a party." 28 The court did not explain why it thought a declaratory judgment has a greater binding effect upon the superior than an injunction.

25. Jacobs v. Office of Housing Expediter, 176 F.2d 338 (7th Cir. 1949).

26. Parker v. Lester, 98 F. Supp. 300 (N.D. Cal. 1951).

27. Cha-Toine Hotel Apartments Bldg. Corp. v. Shogren, 204 F.2d 256, 258 (7th Cir. 1953).

28. May v. Maurer, 185 F.2d 475, 478 (10th Cir. 1950). 
An informed lawyer might have guessed that if a declaratory judgment binds a superior officer in a rent case, a declaratory.judgment ought to bind a superior officer in a customs case, but the guess would be wrong. In a suit for an injunction and a declaratory judgment against a collector of customs, the court held that the Commissioner of Customs was not an indispensable party because ". . . if the court shall conclude that exclusion of the watches was unlawful, all it need do is. to forbid the acting collector from making . . . any exception in the rights of entry secured to the plaintiff by the customs laws and regulations." 29

Post Office employees who sought permanent status and an injunction against discharge were told that ". . . the Postmaster General and the Civil Service Commission are necessary and indispensable parties because their concurrence is necessary to make lawful the relief sought. . . ."30 If the plaintiffs' lawyer had asked only for an injunction against discharge-which was in substance nearly all that the plaintiffs wanted-the court could then have invoked the Williams and the Grimes cases for the conclusion that the decree could expend itself on the subordinates. ${ }^{31}$

The idea that a court cannot compel subordinates to exercise authority which their superiors have not delegated to them is an attractive one-until one sees the impracticability of it. If this idea had governed the Williams case, the Court could not have enjoined the local postmaster, for the Postmaster General clearly had not delegated authority to the local postmaster to lift a fraud order issued by the Postmaster General. Similarly, the Secretary of the Interior had not authorized the Alaskan officials in the Grimes case to permit violations of the regulation issued by the Secretary. If a local officer discharges the plaintiff, may the plaintiff's remedy against the local officer be defeated by withholding from the local officer the authority to reinstate? The answer based on narrow logic is yes; the answer based on common sense and practicality is no. A court of appeals in Money $v$. Walline ${ }^{32}$ said yes on the basis of narrow logic.

In many suits for injunctions or declaratory judgments against enforcement by local officers of deportation orders, the lower federal courts have had to guess whether national officers must be joined-or invent their own law on the subject. The cases, of course, have gone

29. Croton Watch Co. v. Laughlin, 208 F.2d 93, 96 (2d Cir. 1953).

30. McGrimley v. Foley, 89 F. Supp. 10, 12 (D. Mass. 1950).

31. This is the way plaintiffs' lawyers won on the indispensable-superior issue in Reeber v. Rossell, 91 F. Supp. 108 (S.D.N.Y. 1950), and in Farrell v. Moomau, 85 F. Supp. 125 (N.D. Cal. 1949).

32. 186 F.2d 411 (3d Cir. 1951). 
both ways. Most of the courts guessed wrong ábout what the "Sipreme Court would finally hold. ${ }^{38}$

In the celebrated case of government seizure of the steel plant's in 1952, Youngstown Sheet \& Tube Co. v. Sawyer, ${ }^{34}$ an executive order directed the Secretary of Commerce to take possession of the plants. The Secretary took possession and designated the president of each company as operating manager for the United States, subject to the Secretary's supervision. Thereupon the steel companies sought declaratory and injunctive relief in an action against the Secretary: The district court specifically held that the President was "not an in"dispensable party. . . ."35 Yet the power and the responsibility were the President's under the Webster test, and the hands that would be tied by an injunction were the President's under the Rutter test. But with steel for Korea 'awaiting the'decision, and with the whole country watching, would not the Supreme Court have been embarrassed to apply its judge-made technicalities about indispensable superiors?

The Supreme Court's pre-1955 case law, including especially the "principle" laid down in the Williams case, has proved utterly iniworkable in practice. The Supreme Court failed to provide intelligible guides to the lower courts and to litigants. Furthermore, the crucial distinctions between action and inaction and between acts of $\mathbf{a}$ subordinate and acts of a superior through a subordinate seldom have any relation to the merits of the question whether the superior officer should be joined.

The realities of the problem do not lie in such conceptual distinctions but lie elsewhere: (1) The central question is one of venue, which in turn has to do with geography and traveling expenses. (2) Gov-

33. In Shaughnessy v. Pedreiro, 349 U.S. 48 (1955), discussed at pp. 78-79 infra, the Court held that the superior 'need not be joined. Lower: courts had held that the superior must be joined, Rodriguez v. Landon, 212 F.2d 508 (9th Cir. 1954); Paolo v. Garfnkel, 200 F.2d 280 (3d Cir. 1952); Slavik y. Miller, 184 F.2d 575 (3d Cir. 1950), cert. deried, 340 U.S. 955 (1951); Podovinnikoff v. Miller, 179 F.2d 937 (3d Cir. 1950); Gong Poy v. Sahli, 125 F. Supp. 740 (N.D. Ill. 1954); Corona v. Landon, 111 F. Supp. 191 (S.D. Cal. 1953); Birms v. Commissioner; 103 F. Supp. $180^{\circ}$ (N.D. Ohio 1952); Medalha v. Shaughnessy; 102 F. Supp; 950 (S.D.N.Y. 1951). Lower courts had held that the superior need not be joined in Pedreiro v. Shaughnessy, 213 F.2d 768 (2d Cir. 1954), aff'd, 349 U.S. 48 (1955); Dragna v. Landon, 209 F.2d 26 (9th Cir. 1953); Ragni v. Butterfield, 115 F. Supp. 953 (E.D. Mich. 1953); Navarro v. Landon, 106 F. Supp. 73 (S.D. Cal. 1952).

The honors go to Judge Picard, who ignored the conceptual distinctions the Supreme Court had drawn and decided on the ground that ". . . to require a litigant to travel thousands of miles to prosecute a legal claim is not only unjust and highly inequitable but virtually a denial of the right to bring suit.". Ragni.v. Butterfield, supra at 955 . This is the ground on which the Supreme Court later decided in Shaughnessy v. Pedreiro, supra at .53." (1952).

34. 103 F. Supp. 569 (D.D.C. 1952), a.f'd on other grouinds, 343: .U.S. 579

35. Id. at 576 . 
ernment attorneys, who are stationed throughout the land, defend the suit whether or not the superior is joined, because the problem of joining the superior arises only when the real defendant is the government. (3) When government attorneys defend the suit because the government is the real party in interest, a judgment or decree against the subordinate must be res judicata against the government and against other government officers, unless the same question is to be litigated a second time between the real parties in interest. ${ }^{36}$ (4) When government administration is decentralized, so that action is taken or withheld by local officers, judicial review may appropriately be similarly decentralized.

The Supreme Court in 1955 has at last taken into account such realities as these and has apparently departed completely from the earlier conceptualism. In Pedreiro $v$. Shaughnessy, an alien sought to challenge a deportation order in a suit against the district director for an injunction and declaratory judgment. The Court held that the Commissioner of Immigration and Naturalization was not an indispensable party because "otherwise in order to try his case an alien might be compelled to go to the District of Columbia to obtain jurisdiction over the Commissioner. To impose this burden on an alien about to be deported would be completely inconsistent with the basic policy of the Administrative Procedure Act to facilitate court review of such administrative action. We know of no necessity for such a harsh rule. Undoubtedly the Government's defense can be adequately presented by the District Director who is under the supervision of the Commissioner." 37

This ground for decision is both entirely new and entirely sound. It should become the foundation for future law.

The Court in the Pedreiro opinion gave only a partial and somewhat unsatisfactory answer to the question of res judicata. To the argument that a judgment against the district director would not be binding in other immigration districts, the Court said: "But we need not decide the effect of such a judgment. We cannot assume that a decision on the merits in a court of appeals on a question of this kind, subject to review by this Court, would be lightly disregarded by the immigration authorities." 38 This statement may be true as far as it goes. But what if a judicial decision in the other district has held the opposite, or what if the officer in the other district believes that the court is wrong and would be reversed if the case were appealed? The

36. See the discussion at p. 79 infra.

37. 349 U.S. at 53.

38. Ibid. 
question of the binding effect of the court's decision may well arise. Except for some remarks about habeas corpus; ${ }^{39}$ the Court in the Pedreiro opinion went no further into the problem of res judicata.

The Court could easily have examined its earlier decisions and have found that even though the Court has failed to enunciate clear and consistent law on the question whether a judgment in a suit against an officer is res judicata against the government and hence against other officers, yet the authority that such a judgment is res judicata is probably stronger than the opposing authority. ${ }^{40}$ The Court could also easily have recognized that reason and policy are strongly on the side of res judicata, for after a case has been litigated between a private party and government attorneys who are representing the government's interest even though the nominal party is an officer, the government should be bound in the same way that any other litigant would be bound, unless the unsatisfactory doctrine of. sovereign immunity is to be expanded into doubtful territory.

Now that the Pedreiro case has at last recognized that the requirement of joining superior officers should be governed by practicalities concerning geography and convenience, what is the law of the future? Although the eight Supreme Court decisions are seriously conflicting both in their holdings and in their grounds for decision, and although such inconsistency is seldom eradicated by a single decision, yet the Pedreiro opinion makes such a significant advance over the earlier decisions that one may hope and expect that it will become the foundation for the further development of law.

The guiding principle probably should be: Whenever the government is administering a program through a local officer, the validity of his action or refusal to act may be challenged in a suit against the local officer without joining superior officers, whether or not a judgment or decree granting the relief sought will require action by superior

39. The Court said: "Nor is it to be assumed that a second effort to have the same issue decided in a habeas corpus proceeding would do any serious harm to the Government. In habeas corpus proceedings district courts would have the duty to consider previous court decisions on the same matter. And even though in extraordinary circumstances new matters not previously adjudicated may arise in habeas corpus proceedings, this is no adequate reason for subjecting an alien to the great burden of having to go with his witnesses to the District of Columbia..." Ibid.

The particular problem of the Pedreiro case may be affected by the doctrine, not here developed, that denial of a petition for habeas corpus is not res judicata for purposes of a new petition for habeas corpus. United States ex rel. Accardi v. Shaughnessy, 347 U.S. 260, 263 (1954); Salinger v. Loisel, 265 U.S. 224, 230 (1924).

40. For discussion of the Supreme Court's conflicting decisions on the question whether judgments in suits against officers are res judicata against the government when government counsel defend, see Davis, Sovereign Immumity in Suits Against Officers for Relief Other Than Damages, 40 CoRNell L.Q. 3, 30-35 (1954). 
officers. This principle is in all respects consistent with the holding's. in the Williams, Toll, Grimes; and Pedreiro cases, ${ }^{41}$ and the reasons for the principle are those stated in the Pedreiro opinion. The only substantial reason against this principle is the notion that a challenge of an administrative policy is more appropriate in a suit against the officer who has determined the policy than in a suit against a subordinate who has not made the determination but is merely carrying it out; this notion is clearly rejected by the Williams, Toll, and Grimes holdings, in each of which the enforcement of policies determined by superior officers was enjoined even though the superior officers were not before the court. ${ }^{42}$

The central principle should be implemented by several subsidiary propositions: (1) The courts should consistently hold, as the Supreme Court specifically held in the Williams and Grimes cases, that a decree may be issued against a subordinate even though his compliance will mean violation of instructions from his superiors or violation of formal regulations issued by his superiors. ${ }^{43}$ (2) Such distinctions as those between action and inaction, between injunctive and mandatory relief, and between an act of a subordinate and an act of a superior through a subordinate should no longer have any significance in determining whether a superior must be joined.4. (3) The idea of the Rutter.

41. The proposed principle is not altogether consistent with the four cases that have held the superior officer an indispensable party. Blackmar v. Guerre, 342 U.S. 512 (1952); Webster v. Fall, 266 U.S. 507 (1925); Gnerich v. Rutter, 265 U.S. 388 (1924); Warner Valley Stock Co. v. Smith, 165 U.S. 28 (1897). The Rutter and Webster cases are inconsistent with the later Williams, Toll, and Grimes cases and therefore should be deemed already superseded. The Warner case may be explained as meaning only that the Secretary is an indispensable party when the relief sought is directly against the Secretary, not against-a subordinate. The Blackmar case is weak authority, because the question of relief against the regional officer was disposed of with the cryptic remark that ". . . it is obvious that no relief can be granted against him," whereas it should be "obvious" that relief can be granted against an individual who has committed the wrongful act. The Blackmar remark should not be followed.

42. In Williams, the local postmaster was enjoined from enforcing a fraud order issued by or in the name of the Postmaster General. In Toll and in Grimes, local officers were enjoined from enforcing regulations issued by their superiors in Washington.

When a government program requires uniformity of action, as did wartime price control, the statute usually provides for centralization of judicial review, as it: did in that instance. 56 STAT. 31 (1942), 50 U.S.C. APP. $\$ 924$ (1952). . Cf. Yakus v. United States, 321 U.S. 414 (1944)

43. See notes 18,19 , and 20 supra.

44. The question may be asked: How can a court compel an affirmative act by a superior officer who is not a party to the case? The main answer to this question lies in emphasizing that the proposed principle is limited to programs which are administered by local officers; the decree will run only against the local officer, just as in the Williams case the Court nullified the fraud order issued by the Postmaster Gerieral even though only the local postmaster was before the Court, and just as in the Grimes and Toll cases, the Court nullified regulations issued by national officers even though only local officers were before the Court:

Of all the cases mentioned in this commentary, not a single orie involves the problem of whether a court outside the District of Columbia may order a superior 
case that a superior is indispensable if his hands will be tied and the idea of the Webster case that a superior is indispensable if the power and responsibility are his have already been superseded by the holding of the Williams case, where the Supreme Court approved a' decree which tied the hands of the Postmaster General even though the powerand responsibility were the Postmaster General's. The two ideas of the Rutter and Webster cases should not be revived."5 (4) A local officer who has taken, is taking, or is threatening to take the challenged action should be deemed to have the authority to refrain from or to undo the challenged action if the court holds the action to be illegal and if the decree is otherwise fitting in the circumstances. (5) The Supreme Court should follow its own decisions holding that a judgment or decree against a local officer in a case defended by government attorneys is res judicata against the government and against. other government officers, whether the judgment or decree is coercive or declaratory, and it should refuse to follow its holdings and dicta to the contrary. ${ }^{47}$

officer in Washington to perform an affirmative act, where a decree against the subordinate would not suffice. Warner Valley Stock Co. v. Smith, 165 U.S. 28 (1897), does not qualify, for the suit was brought in the District of Columbia. If the problem should arise, as it conceivably could, the ingenuity of an equity judge could take care of it. A declaratory judgment could be granted even though the. superior is not before the court and even though compliance with the declaration would require the superior to take affirmative action. The court could also grant a mandatory injunction ordering the subordinate to transmit the decision and the order to the superior, and, depending on circumstances, the subordinate could be enjoined' from further action against the plaintiff until the superior officer has complied.

In the exceedingly unusual. case in which a superior officer refuses to comply, a suit against the superior could be brought in the District of Columbia. The decision against the subordinate would be res judicata. See note 40 supra.

45. The Secretary in the Webster. case had delegated authority to local disbursing officers to make payments of money. Even though the plaintiff sought a mandatory decree, and even though the responsibility was the Secretary's, the decree could be enforced against the local officers. If the program had not been administered through the local officers, then a court might properly hold the Secretary to be an indispensable party.

Lower federal courts have recently held in many cases, following Palmer v. Walsh, 78 F. Supp. 64 (D. Ore. 1948), that federal courts outside the District of Columbia cannot grant mandatory relief. But this line of cases is contrary to the Supreme Court's practice in such cases as Virginian Ry." v. System Federation '40, Railway' Employees Dep't, AFL; 300 U.S. 515 ' (1937), and Johnson v. 'Yellow Cab Transit Co., 321 U.S. 383 (1944), contrary to the provision of $\$ 10(\mathrm{~b})$ of the Administrative Procedure Act that relief from administrative action may include. "mandatory injunction," 60 STAT. 243 (1946), 5 U.S.C. \$1009(b) (1952), and contrary to the provision of $\S 10(\mathrm{e})(\mathrm{A})$ of the APA that the reviewing court

shall . compel agency action unlawfully withheld. . : 60 STAT. 243 (1946), 5 U.S.C. $\$ 1009$ (e) (A) (1952). See Davis, Mandatory Relief from Adminstrative Action, 22 U. CerI. L. REv. 585 (1955).

46. This is to prevent an unfortunate result like that in Money v. Wallin, 186. F.2d 411 (3d Cir. 1951), in which the local officer' discharged the plaintiff, but the court held that the local officer had no delegated authority to reinstate the plaintiff. Whatever strict logic may. require, practicality requires that an officer should be deemed to have authority to correct the illegality of his action.

47. See note 40 stipra. 
The basic approach of the Pedreiro opinion should govern the law of the future. Judicial thinking about this problem should revolve around the practicalities of geography and convenience, not around logical distinctions between inaction and affirmative action or between acts of subordinates and acts of superiors through subordinates. ${ }^{48}$

\section{Substitution of Officers' Successors}

"It all seems so foolish. Some day the rule will be amended." 49

These were the words of a perceptive district judge, who felt constrained by authority to apply the rule that an action against an officer abates when the officer dies, resigns, or otherwise ceases to hold office unless a timely substitution is made of his successor.

The Advisory Committee on Rules for Civil Procedure seems to have the same insight as the district judge, for in its comment on rule 25 (d), it has wisely observed that "the substitution of one nominal party for another nominal party is a time-consuming formality." so Strangely enough, however, the Advisory Committee does not have the courage of its convictions, for instead of proposing that the rule be amended to dispense with what is admittedly a "time-consuming formality," the Committee has recommended a retention of the requirement of timely substitution!

The purpose of this commentary is to demonstrate that the requirement of substitution of officers' successors is causing a good deal of avoidable harm, and to propose that the requirement should be discontinued. The discussion will conclude with a specific proposal for amending rule $25(\mathrm{~d})$.

The cornerstone of the present law is Snyder v. Buck. ${ }^{51}$ A widow sued Buck, the Paymaster General of the Navy, for an allowance, and the district court entered a judgment which concluded: ". . . and the defendant is directed to pay the plaintiff Thirteen Hundred and

48. Of course, other solutions of the basic problem could be provided either by statute or by amendment of rule 19 of the Rules of Civil Procedure.

A little reflection on a practical plane will show how anachronistic and unnecessary is the idea of service of process upon government officers, as distinguished from notice to the government's attorneys.

For an example of a statute which provides for suit against national officers in the district court where the plaintiff resides or where the plaintiff corporation has its principal place of business, see 40 STAT. 419 (1917), 50 U.S.C. APP. § 9(a) (1952).

For commentary on the main problem, see Notes, 103 U. PA. L. REv. 238 (1954), 54 CoLUM. L. Rev. 1128 (1954), 23 IND. L.J. 305 (1948), 50 YALE L.J. 909 (1941), 50 Harv. L. Rev. 796 (1937), 4 U. ChI. L. Rev. 342 (1937).

49. Rosello v. Marshall, 12 F.R.D. 352, 355 (S.D.N.Y. 1952) (Liebell, J.).

50. Preitalinary Draft of Proposed Augendments to Rules of Civll ProCEDURe FOR the UNIten States District Courts 20 (May 1954).

51. 340 U.S. 15 (1950). 
Sixty-five Dollars." After the judgment had been entered, Buck retired and was succeeded by Foster. Then government attorneys took an appeal in the name of Buck, or, as the Supreme Court unrealistically expressed it, ". . . the appeal was taken by Buck after his retirement and therefore without authority." 52 Neither party substituted Foster's name for Buck's within six months after Foster's succession. The Supreme Court held that the action abated.

Even though the judgment in favor of the widow was valid when it was entered, and even though the principal fault was that of the government attorneys in taking the appeal in the name of Buck instead of in the name of Foster, yet the Court held that "Petitioner [the widow] loses her judgment and must start over." 53

If the government attorneys (or their stenographer) had only remembered that the name of Foster should have been substituted for the name of Buck, the widow's judgment would not have become void on account of Foster's succession to the office of Paymaster General. But the government attorneys (or their stenographer) used the wrong name. So the widow lost her judgment. The principle of justice seems to be that when one party's attorneys (or their stenographer) are at fault in failing to substitute the name of the successor officer, the court should penalize the opposing party. ${ }^{54}$

The holding rests upon interpretation of section 11 of the Judiciary Act of 1925.5s During the nineteenth century, it had been held that an action aimed at compelling an official to discharge his official duties abated when the official died or retired. ${ }^{56}$ A statute of 1899 provided that no such action should abate. ${ }^{57}$ But section 11 of the 1925 Act provided that the court could permit such an action to be continued against the successor "if within six months after his death or separation from office it be satisfactorily shown to the court that there is a substantial need for so continuing. . . ." 58 The Court interpreted these words to make survival of the action dependent upon timely substitution of the successor.

52. Id. at 20 .

53. Id. at 22 .

54. Either the government attorneys or the attorney for Mrs. Snyder could have made timely motion to substitute Foster's name for Buck's. The primary responsibility was that of the government attorneys, for the simple reason that they were the representatives of Buck and of Foster and of the government.

55. 43 Stat. 936, 941 (1925). See also Fed. R. Civ. P. 25(d); U.S. Sur. CT. REv. RuLE 48(3).

56. E.g., Warner Valley Stock Co. v. Smith, 165 U.S. 28 (1897).

57. 30 Stat. 822 (1899).

58. The 1925 act extended the 1899 act to apply to successors of state officers as well as federal. 
Mr. Justice Frankfurter, joined by Mr. Justice Jackson, argued in dissent that the 1925 legislation was intended to have the same effect as the 1899 legislation, that the suit was in reality a suit against the United States, that the suit could have been brought against the United States in the Court of Claims, and that sovereign immunity should not stand. in the way when consent has been given to a suit in another forum: "Accordingly, I would recognize that the judgment of the District Court is in effect a money judgment against the United States and would allow the Government's notice of appeal the force it 'was intended to have as an effective instrument whereby the United States might obtain a review of that judgment. It would be nothing novel in the observance of decorous form by courts to note as a matter of record that the name of the Paymaster General of the Navy is now Fox [Foster] and to proceed with the appeal on that basis." 59

Mr. Justice Clark, joined by Mr. Justice Black, agreed with the majority that the appeal should fail but dissented from the order vacating the judgment of the district court.

The confusion of reality and pretense becomes especially interesting. The reality is: the court's judgment was an order to pay government money to the plaintiff. The pretense is: the defendant was Admiral Buck, not the government. In the present stage of judicial making and unmaking of the law of sovereign immunity, the law permits a court to order a government officer to pay government money' to the plaintiff but forbids a court to order the government to pay government. money to the plaintiff. The plaintiff, to win, must pretend that his suit for government money is not against the government. The court must indulge in the same pretense.

The opinion in Snyder $v$. Buck is remarkable for the fluctuation within the single case between pretense and reality. The holding rests squarely on the pretense that the suit was not against the government; even though nothing about the doctrine of sovereign immunity required the Court to reject the reality on the question of substituting the name of Foster for that of Buck.

Even though the holding rested upon the pretense, every one of the three opinions explicitly recognized the falsity of the pretense. $\mathrm{Mr}$. Justice Douglas said for the majority: "Many actions against an official. relating to the 'discharge of his official duties' would in substance be suits against the United States." 60 Mr. Justice Frankfurter spoke of ". . . litigation brought formally against an official but intrinsically

59.340, U.S. at 31 .

60. Id. at 20 . 
against the Government. : . . " 01 . And Mr. Justice Clark said “ it is clear that petitioner's claim, is against Buck in his 'representative capacity, not personally." 62

Since the justices not only knew, but even acknowledged, that the judgment ordered a payment of the government's money and was only in form against Buck, the Court could easily have written a simple opinion that good sense requires that Buck's successor; Foster, 'or his assistants, should make the payment of government money to the widow..$^{\text {B }}$

But instead of restricting the law of Snyder v. Buck, the Supreme Court has recently expanded it. Unbelievable as it may seem, an otherwise valid judgment can now be rendered void by the succession of one officer to another even though both parties make timely motions to substitute the successor's name. In McGrath v. National Association of Manufacturers, ${ }^{\text {b4 }}$ the NAM sued McGrath, the Attorney General, to enjoin prosecution for violation of a statute. The three-judge district court handed down an opinion on March 17, 1952, holding the statute unconstitutional. McGrath resigned April 7, 1952. The judgment was entered against him May 2, 1952, to take effect March 17, 1952. McGranery succeeded to the office May 27, 1952. The government took the appeal to the Supreme Court in the name of -McGrath "or, in the alternative, his successor in office, James P. McGranery, or, in the further alternative, the United States." In a statement as to jurisdiction, the Solicitor General explained the facts and said: "It is respectfully requested and moved that the appeal be deemed taken on behalf of Mr. McGranery, the present Attorney General, and that the latter be substituted as appellant in place of Mr. McGrath." On October 2, 1952, less than six months after the resignation $\cdot$ of $\cdot M c G r a t h$, the NAM filed a "Motion to Substitute James P. McGranery for J. Howard McGrath."

Despite the timely motions made by parties on both sides to substitute one name for the other, the Supreme Court on October 13, 1952, entered a per curiam order: "The judgment is vacated and the case is remanded to the United States District Court with directions to dismiss the complaint upon the ground that the case is moot." The

61. Id. at 22 .

62. Id. at 32-33.

63. The statute the Court discussed in the opinion was susceptible of an interpretation that would produce a practical result. The law is what it is, not because of Congress, but because of the Supreme Court. As the Court observes in its opinion in Siryder v. Buck (340 U.S. at 25), both the 1899 statute and the 1925 statute were enacted upon the recommendation of the judges.

64. 344 U.S. 804 (1952). 
Court cited Snyder v. Buck, but gave no additional reason. The Court denied rehearing November 17,1952 , two justices dissenting..$^{65}$

The fortuitous fact that one officer succeeded another resulted in a holding that a judgment in a suit which was in reality against the government was void, even though timely motion was made by both parties to substitute the successor.

The lower courts have generally felt obligated to follow Snyder $v$. $B u c k$ and to apply the principle, not merely when an appeal is taken in the name of an officer who has retired, but to apply it whenever during litigation one officer is succeeded by another ${ }^{68}$ One court states the typical attitude: "This is a harsh rule, but under the decisions of our highest court the rule is mandatory and allows no discretion to the district judge." $6 \mathrm{r}$

The Court of Appeals for the Ninth Circuit has found an ingenious way out when the suit is only for a declaratory judgment. The suit was for a declaration of citizenship under the Nationality Act of 1940 before that act was superseded. The parties had failed to make timely substitution of Dulles for Acheson. The court comprehensively reviewed the cases and found that the only reason for abatement was the futility of issuing an order against one who cannot comply because he is dead or out of office. But a declaration requires no one to do anything. A declaration of citizenship is just as good against Acheson as it is against Dulles, for it is ". . . as binding to the world as it is to the defendant officer. . . ." 68 The opinion of the Ninth Circuit was so persuasive that the Third Circuit reconsidered a decision abating an action of the same sort and followed "the excellent opinion of the Ninth Circuit." 69 One may hope that other courts will also follow the Ninth Gircuit.

But the ingenuity of the Ninth Circuit is unfortunately limited to declaratory judgments and does not reach coercive judgments. A change is still needed to reach coercive judgments.

The Advisory Committee on Rules for Civil Procedure has proposed amendment of rule 25 (d) so that "a reasonable time" will be substituted for the period of six months, and so that an officer sued "in his official capacity" may be described by his official title and not

65. 344 U.S. at 887.

66. Rosello v. Marshall, 12 F.R.D. 352 (S.D.N.Y. 1952); Joji v. Clark, 11 F.R.D. 253 (N.D. Cal. 1951); Schnoedewind v. Clark, 11 F.R.D. 107 (S.D.N.Y. 1950); Wisconsin v. Clark, 11 F.R.D. 103 (W.D. Wis. 1950).

67. Rosello v. Marshall, supra note 49 , at 354.

68. Acheson v. Furusho, 212 F2d 284, 292 (9th Cir. 1954).

69. Lehmann v. Acheson, 214 F.2d 403, 404 (3d Cir. 1954); accord, Lew Thun v. McGrath, 16 F.R.D. 352 (S.D.N.Y. 1954). 
by name. ${ }^{70}$ The first proposal is faulty in that it wrongly assumes the need for substitution; substituting one nominal party for another serves no useful purpose. The second proposal is shockingly unfortunate because it leads directly into a legal quagmire. Three kinds of suits may be brought against officers: (1) suits against officers personally, and in no sense against the government; (2) suits nominally against officers personally, but in reality against the government; and (3) suits nominally against officers in their official capacity, but in reality against the government. . The distinction between the first and the other two is almost always easy and clear; the rule might well be founded upon it. The distinction between the second and the third is the legal quagmire; to found the rule upon it is an invitation to fruitless litigation.

In the leading case of United States $v$. Lee, ${ }^{71}$ which was a suit for land claimed by the government, the Court said that the case was “. . against Strong and Kaufman, as individuals, to recover possession. . . ."72 In another leading case, Ex parte Young, ${ }^{73}$ the theory was that when an officer acts without valid authority he is ". . . stripped of his official or representative character and is subjected in his person to the consequences of his individual conduct." 74 The theory of the case was that the capacity of the officer was personal or individual, not official. Probably the usual formulation in more recent times is that of Georgia $R . R$. \& Banking Co. v. Redwine: "This Court has long held that a suit to restrain unconstitutional action threatened by an individual who is a state officer is not a suit against the State. . . This general rule has been applied in suits against individuals threatening to enforce allegedly unconstitutional taxation. . . . We hold that this action against appellee as an individual is not barred as an unconsented suit against the State." 78

But in other opinions, for no apparent reason, the Supreme Court has assumed that the suits are against officers as officers or in their official capacity, and not against the officers as individuals or in their personal capacity. In Garfield v. United States ex rel. Goldsby, ${ }^{77}$ the Court seemingly went out of its way in granting mandamus against an officer to say that the order was against the defendant ". . . in

70. Pretcminary Draft of Proposed Amendments to Rules of Ctvil Procedure For the United States District Courts 18 (May 1954).

71. 106 U.S. 196 (1882).

72. Id. at 210 .

73. 209 U.S. 123 (1908).

74. Id. at 160 .

75. 342 U.S. 299 (1952).

76. Id. at 304-05.

77. 211 U.S. 249 (1908). 
his official capacity. ... . ${ }_{3:}^{78}$ In the key case of this commentary, Snyder v. Buck, the Court said that the judgment was ‘. . . against -respondent in his official capacity as Paymaster General of the Navy.". 79 In the important recent case of Larson v. Foreign \& Domestic.Commerce Corp. ${ }^{80}$ the Court said that the suit was against the officer " $\because$ because of his official function as chief of the War Assets Administration. . It asked for an injunction. against him, in that capacity. . ..." 81

None of these various opinions attempts an explanation of why suits which are in reality against the government are sometimes assumed to be against the officers as individuals and why they are sometimes assumed to be against the officers as officers. Probably most of the remarks just:quoted were uttered without any special consideration of this question. But a plaintiff in 1944 lost his case in the Supreme Court because he sued the officer "officially" instead of "personally." The Court" said that the suit "was against the official, not the individual," and implied that if. it had been against the individual, not the official, the case might have been considered on the merits. ${ }^{82}$ The de'cision has been followed by two later Supreme Court cases. ${ }^{83}$

A rule cannot be satisfactory which is based upon a distinction between (1) suits which are in reality against the government but nominally against an officer. as an officer or in his official capacity, and (2) suits which are in reality against the government but nominally against an officer as an individual or in his personal capacity. ${ }^{84}$

A workable rule should rest upon a distinction which is almost always clear and easy-the distinction between a suit which is in reality against the government and a suit which is not in reality against the government. An amendment of rule 25(d) should be based upon this distinction.

True, to acknowledge in a formal rule that a suit is "in reality" against the government is to contribute to the erosion of the doctrine of sovereign immunity. But that is a virtue. As long as the doctrine of sovereign immunity is retained, lawmakers should lose no oppor-

78. Id. at 255 .

79. 340 U.S. at $15-16$.

80. 337 U.S. 682 (1949).

81. Id. at 686 .

82. Great Northern Ins. Co. v. Read, 322 U.S. 47, 53 (1944).

83. Kennecott Copper Corp. v. State Tax Commission, 327 U.S. 573 (1946); Ford Motor Co. v. Department of Treasury of Indiana, 323 U.S. 459 (1945).

84. No difference is discernable between a suit against an officer as an officer and a suit against an officer in his official capacity. Apparently neither expression will apply to cases like Lee, Young and Redwine, if the 'terminology of those opinions is to be believed. 
tunity to weaken or restrict it. Frank acknowledgment in a formal rule that a suit may be "in reality" against the government will go no further than to bring the rule abreast of what each of the three opinions in the Snyder case has already frankly acknowledged.85 Furthermore, the proposal that the rule be framed in terms of suits which are "in reality" against the government does not cut into the tradition of sovereign immunity to any greater extent than the Advisory Committee's proposal to permit suits against officers who are described only by their official titles. ${ }^{86}$

The paramount objective of a rule which is sensible and workable should be to get rid of the "time-consuming formality" of substituting one nominal party for another nominal party.

Accordingly, the main provision of rule 25 (d) of the Rules of Civil Procedure should be amended so that the substance will be along the following line:

When an action is by or against a public officer in name but is by or against the government in reality, the substitution of one nominal party for another nominal party is not required. Any judgment or decree for or against an officer in such a case shall describe him by his official title and shall be enforceable by or against the incumbent of the office at the time of enforcement.

85. See notes 60,61 and 62 supra.

86. When the government is the real defendant, a judgment or decree against Acheson is binding upon Dulles, upon Dulles' successors, upon Dulles' subordinates, and upon the government, according to the stronger authority. The authorities on this question of res judicata are discussed in Davis, Sovereign Immunity in Suits Againist Officers for Relief Other Than Damages, 40 CORNELI L.Q. 3, 30-35 (1954).

The only reasons that can be given for substituting the name of Dulles for the name of Acheson are (1) so that the order will be enforceable against Dulles, and (2) so that the order will not be enforceable against Acheson. But both reasons are automatically satisfied without the substitution. Whenever the government is the real defendant, an order against Acheson is enforceable against Dulles. And whenever the government is the real defendant, an order will be enforced against the incumbent officer, not against the former officer.

As is fully shown in the article just cited, Supreme Court cases on sovereign immunity in suits against officers are so diverse that almost any formal rule is likely to cut into one or more individual decisions. The rule here proposed will probably change the result in the very extreme decision of Ex parte La Prade, 289 U.S. 444 (1933), where the Court held that a threat of enforcement by an attorney general whose term of office then expired was not enough to make the challenge of the statute ripe for consideration, even if the successor attorney general were substituted. If the proposed rule weakens the law of the La Prade case, so much the better. The Advisory Committee's proposal to describe the officer by official title instead of by name would to the same extent weaken the law of the La Prade case. 